\title{
Renal Function after Leptospirosis
}

\author{
B. SIMPSON,* M.A., M.B., M.R.C.P.ED.; A. T. COOK, $†$ M.B., M.R.C.P. ; A. H. DIMOND, $\ddagger$ M.A., M.B., M.R.C.P. \\ M. BROWN, $\S$ M.B., M.R.C.P. ; R. N. T. THIN, $\S$ M.B., M.R.C.P.ED.
}

Brit. med. F., 1967, 3, 472-473

It is generally assumed that a patient who survives an attack of leptospirosis is left with normal kidneys (Van Thiel, 1948; Gsell, 1952 ; Ross Russell, 1959), but no long-term follow-up study has been published and certain facts suggest the need for such an investigation. Firstly, the frequency of renal damage in this disease is illustrated by the reports of Penna et al. (1963) and de Brito et al. (1965) in Brazil ; they obtained renal biopsy specimens between the eleventh and forty-fifth days of the illness, and even in patients with minimal impairment of renal function they demonstrated infiltration of the interstitial tissue with lymphocytes and histiocytes, tubular damage, focal thickening of the glomerular basement membrane, and objects resembling leptospirae. Further, leptospiruria is not uncommon and may persist for as long as 11 months (Johnson, 1950); indeed, Spînu et al. (1962), who studied an epidemic outbreak of leptospirosis in Vietnam, concluded that in certain circumstances human excreters might be the source of spread. It thus seems possible that leptospirosis might cause chronic renal damage and impairment of renal function, and this paper describes an investigation into this aspect.

\section{Present Investigation}

Our patients were soldiers who contracted leptospirosis in South-East Asia, where the disease is an important military problem and caused 333 admissions to hospital in 1954-5 (Levis, 1957). Renal damage provides the main problem in management, though since the introduction of rational conservative therapy for uraemia the main cause of death in the few fatal cases (less than $2 \%$ of patients) has been haemorrhage (Trimble, 1957). Thirty serotypes have been incriminated in this group (Alexander et al., 1957), including Leptospira icterohaemorrhagiae and L. canicola, and there is no correlation between the serotype responsible for the illness and the severity of the renal lesion, jaundice, or meningitis. This finding is in accord with the experience of Continental workers (Gsell, 1952), but differs from the pattern hitherto reported in Britain, where jaundice due to L. icterohaemorrhagiae and meningitis due to L. canicola are the commonly diagnosed forms of leptospirosis.

Subjects.-Nineteen British and 25 Gurkha soldiers had contracted leptospirosis between 1 and 14 years previously (mean eight years), when aged 18 to 28 . Of these, four had developed anuria with a blood urea level of over $350 \mathrm{mg} . / 100$ $\mathrm{ml}$. and two required haemodialysis, in eight the blood urea level had exceeded $150 \mathrm{mg} . / 100 \mathrm{ml}$., and the remainder had normal or slightly impaired renal function with albumin, cells, and granular casts in the urine. The original clinical diagnosis had been confirmed by laboratory and serological findings (Trimble, 1957 ; Ross Russell, 1959). Most of the patients had been treated with large doses of penicillin by intramuscular injection; this drug shortens the duration of the illness and may produce a Herxheimer type of reaction (Mackay-Dick and Robinson, 1957). The patients were selected solely on grounds of availability and represent aproximately a $30 \%$ sample of

- Major, R.A.M.C.; Queen Alexandra Military Hospital, Millbank, London S.W.1.

† Lieutenant-Colonel, R.A.M.C.; British Military Hospital, Singapore. ₹ Major. R.A.M.C. ; British Military Hospital, Hong Kong.

S Major, R.A.M.C.; British Military Hospital, Terendak, Malaysia. currently serving soldiers who have had leptospirosis. As no soldier has been medically discharged from the Army because of this disease it is unlikely that our series is biased in favour of the fittest.

Methods.-Each patient was admitted to hospital for assessment. Biochemical methods were as described by Varley (1962). Urine specific gravity was measured at room temperature $\left(15-23^{\circ} \mathrm{C}\right.$.) by standard hydrometers. In the urine concentration test dehydration was not prolonged beyond 16 hours.

\section{Results}

No patients had symptoms or were anaemic $(\mathrm{Hb}<13.5$ g./ $100 \mathrm{ml}$.) and only one was hypertensive (B.P. $>130 / 90 \mathrm{~mm}$. $\mathrm{Hg}$ ). His B.P. was $115 / 70$ at the time of the attack, but three years later it was 170/120 and the E.C.G. showed hypertensive changes.

Examination of two fresh morning midstream specimens of urine for albumin, glucose, and deposit gave normal results. The blood urea level (mean of two estimations) was in the range 16-35 mg. $/ 100 \mathrm{ml}$. The creatinine clearance, corrected to a body surface area of 1.73 sq. m., was twice estimated over 24 hours in the British soldiers and exceeded $90 \mathrm{ml} . / \mathrm{min}$. in all except one. In this patient, who was not hypertensive, the values were 60 and $63 \mathrm{ml} . / \mathrm{min}$., but the results of other tests (including kidney length as visualized on a plain $x$-ray film) were normal. Single estimations of the creatinine clearance in eight Gurkha soldiers investigated in one hospital (group A) gave values of over $90 \mathrm{ml} . / \mathrm{min}$. Of the 17 assessed elsewhere (group B), seven had values of less than $90 \mathrm{ml} . / \mathrm{min}$., but the serum creatinine levels were similar to those of the patients with normal clearances.

All the British patients concentrated urine to a specific gravity of at least 1020 and diluted to a specific gravity of at least 1002, the narrowest range being 1022-1002. The resuits were similar in the Gurkha patients in group $B$, but of the eight in group A five did not concentrate to this degree.

A plain $x$-ray film of the renal area was taken in each case and it was possible to measure the length of both kidneys in 12 ; the overall range was $12-14.5 \mathrm{~cm}$., and in no instance did the difference between the two sides exceed $1 \mathrm{~cm}$. Intravenous pyelograms were performed in four men (including the patient with hypertension) who were reviewed between one and eight years after the attack of leptospirosis ; all showed normal renal anatomy and secretion. In two of these patients ${ }^{131} I$ Hippuran renograms were performed, with normal results.

There was no correlation between the severity of the initial renal lesion and the blood urea level, creatinine clearance, and maximum specific gravity of the urine, nor did the length of the interval betwen the acute attack and reassessment influence these results.

Dr. L. H. Turner, of the London School of Hygiene and Tropical Medicine, examined the sera of 12 British patients, using pools of formolized leptospiral antigens based on the currently accepted arrangement of serogroups and designed to detect all known pathogenic serotypes. Each showed agglutinin titres of $1: 30$ to $1: 100$ against at least two, and in some 
instances six, serotypes. In only two were the maximum titres against the serotypes responsible for the original infection.

\section{Discussion}

Our results suggest that the long-term prognosis after the acute renal lesion of leptospirosis is good. Thus in the British patients all the results of renal function tests were normal except for a slightly reduced creatinine clearance in one man; as the serum creatinine level and other results in him were normal the significance of this isolated finding is doubtful. Another man developed hypertension, but renal damage did not appear to be the cause. One group of Gurkha patients had normal creatinine clearances but all did not concentrate urine adequately, while in the others these findings were reversed; since each abnormality was confined to one group it seems likely that these discrepancies reflect incomplete dehydration and incomplete urine collection respectively.

As intravenous pyelograms were performed in only four patients, and renal biopsy in none, we cannot be certain that permanent minor anatomical damage to the kidneys has not occurred; but as the individual results were not influenced by the severity of the initial renal lesion or the time interval before reassessment it is unlikely that there is an active process present causing progressive destruction of renal tissue.

The finding of leptospiral agglutinins in the sera of the 12 patients examined is of interest, though in only two did the serological pattern parallel that of the original infection. Hart (1967), using the sensitized erythrocyte lysis test, has shown that a small proportion of soldiers serving in jungle areas in South-east Asia develop a rising titre of leptospiral antibodies without clinical evidence of infection, and our patients have served in this area on several occasions since their original illness. It is thus conceivable that they have acquired subclinical infections during this time and that this explains the serological findings. As, however, all our patients showed significant titres of agglutinins, and none of them had a clinical attack, which would be surprising if they were frequently exposed to infection, this explanation may be too facile. Further investigation of this point is required.

\section{Summary}

Renal function was studied in 44 soldiers who had contracted leptospirosis in South-east Asia up to 14 years previously. The findings suggest that renal function is now normal, and individual results do not reflect the severity of the initial renal damage or the time interval before reassessment.

The sera of 12 patients were examined for leptospiral agglutinins. All showed significant titres, but in only two were these against the serotype responsible for the original illness. These results may possibly reflect subclinical leptospiral infections contracted during later periods of service in the same area, but the present evidence is insufficient to allow firm conclusions to be drawn.

We wish to thank Dr. Gordon Smith, Director M.R.E., Porton, and Major-General R. J. G. Morrison, Consultant Physician to the Army, for suggesting and encouraging this investigation; Dr. L. H. Turner for the serological results and advice; Captain K. Hedges, R.A.M.C., for his help in arranging for the investigation of patients under his care; and the Director-General, Army Medical Services, for permission to use case records.

Requests for reprints should be sent to Major B. Simpson.

\section{REFERENCES}

Alexander, A. D., Evans, L. B., Toussaint, A. J., Marchwicki, R. H., and McCrumb, F. R., jun. (1957). Amer. F. trop. Med. Hyg., 6, 871. de Brito, T., et al. (1965). Ibid., 14, 397.

Gsell, O. (1952). Leptospirosen. Berne.

Hart, R. J. C. (1967). To be published.

Johnson, D. W. (1950). Med. f. Aust., 2, 724.

Levis, D. G. (1957). Proc. roy. Soc. Med., 50, 119.

Mackay-Dick, J., and Robinson, J. F. (1957). f. roy. Army med. Cps, $103,186$.

Penna, D., de Brito, T., Aguiar Pupo, A., Marcondes Machado, M., Ayroza Galvão, P. A., and Soares de Almeida, S. (1963). Amer. $\tilde{\jmath}$. trop. Med. Hyg., 12, 896.

Ross Russell, R. W. (1959). Ann. trop. Med. Parasit., 53, 416.

Spînu, I., Topciu, Vl., Trinh Thi Hang Quy, Vo van Hung, Chau xuan Luong, and Le van Tuyen (1962). Arch. roum. Path. exp., 21, 763. Van Theil, P. H. (1948). The Leptospiroses, Leiden.

Trimble, A. P. (1957). Proc. roy. Soc. Med., 50, 125.

Varley, H. (1962). Practical Clinical Biochemistry, 3rd ed., pp. 112, 151,153 . London.

\title{
Effect of Medical and Surgical Vagotomy on Intrinsic Factor Secretion
}

\author{
J. F. ADAMS, * V.R.D., M.D., F.R.C.P.ED., F.R.C.P.GLASG.; A. G. COX,*† M.D., F.R.C.S.ED. \\ ELIZABETH H. KENNEDY,*‡ B.SC. ; J. THOMPSON,*§ M.B., M.R.C.P.GLASG.
}

Brit. med. F., 1967, 3, 473-476

The recent development of in-vitro techniques for the assay of gastric intrinsic factor has made possible the study of the effects of various pharmacological and surgical manœuvres on this facet of gastric secretory function. Using one such technique, we have studied the effects of pharmacological vagal blockade- "medical vagotomy"-in a group of patients with proved duodenal ulceration, and in some of these have also studied the effects of section of the vagus nerves.

\section{Material and Methods}

Twenty-six patients (23 men aged $22-60$ and 3 women aged $42-48$ ) with the clinical and radiological features of chronic duodenal ulceration were studied before operation, and further studies were made in 15 of them after operation. Vagotomy and pyloroplasty were performed on six men and one woman and vagotomy and gastrojejunostomy on six men and two women. The augmented histamine test was carried out in 26 cases before operation and in 15 after operation. Medical vagotomy was carried out in 25 cases before operation. The insulin test was done in 15 cases after operation. The choice of pyloroplasty or gastrojejunostomy was determined by a randomization procedure. The completeness of surgical vagotomy was confirmed in all cases by an insulin test.

The augmented histamine test (Kay, 1953) was performed after an overnight fast. Gastric aspiration was maintained by

\footnotetext{
* Southern General Hospital and University Department of Surgery,
Western Infirmary, Glasgow.

† Now Senior Lecturer in Surgery, Royal Postgraduate Medical School, London.

‡ Now Scientific Officer, National Engineering Laboratory, East Kilbride, Lanarkshire. $\$$ Now Lecturer in Dermatology, University and Western Infirmary,
} 